\title{
Clinodiplosis agerati (Diptera, Cecidomyiidae), a new galling species associated with Ageratum conyzoides (Asteraceae) from Brazil
}

\author{
V. C. Maia ${ }^{a *}$ and L. Araújo ${ }^{b}$ \\ ${ }^{a}$ Departamento de Entomologia, Museu Nacional, Quinta da Boa Vista, s/n, \\ São Cristóvão, CEP 20940-040, Rio de Janeiro, RJ, Brazil

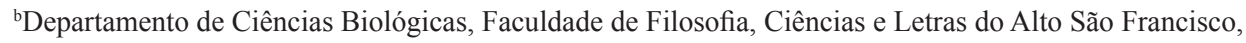 \\ Av. Laerton Paulinelli, 153, Monsenhor Parreiras, CEP 35595-000, Luz, MG, Brazil \\ *e-mail: maiavcid@acd.ufrj.br
}

Received: April 13, 2015 - Accepted: May 7, 2015 - Distributed: August 31, 2016

(With 12 figures)

\begin{abstract}
Clinodiplosis agerati, a new galling species that induces stem galls on Ageratum conyzoides (Asteraceae) is described and illustrated (larva, pupa, male, female and gall) based on material collected in Minas Gerais, Brazil. The new species is compared with the other Neotropical species. This is the first record of the Clinodiplosis in Ageratum.
\end{abstract}

Keywords: gall midge, interaction insect-plant, neotropical, taxonomy.

\section{Clinodiplosis agerati (Diptera, Cecidomyiidae), uma nova espécie galhadora associada a Ageratum conyzoides (Asteraceae) do Brazil}

\begin{abstract}
Resumo
Clinodiplosis agerati, uma nova espécie cecidógena que induz galhas caulinares em Ageratum conyzoides (Asteraceae) é descrita e ilustrada (larva, pupa, macho, fêmea e galha) com base em material coletado em Minas Gerais, Brasil. A nova espécie é comparada com as outras espécies neotropicais. Este é o primeiro registro de Clinodiplosis em Ageratum.
\end{abstract}

Palavras-chave: mosquito de galha, interação inseto-planta, neotropical, taxonomia.

\section{Introduction}

Ageratum conyzoides L. (Asteraceae), commonly known as "mentrasto" or "erva de São João" is a tropical plant, occurring in West Africa, some parts of Asia, Central and South Americas. It is native to tropical America and was introduced in India (Yoganarnarasimham, 2000). It is a wild and ruderal plant, found in dry or humid high areas, in the road margins and crops (Siqueira-Jaccoud, 1961). Ageratum conyzoides has widespread medical use by people from Brazil and other countries due to its antitumoral (Momesso et al., 2009), analgesic (Marques Neto et al., 1988), and muscle relaxation activity (Achola et al., 1994).

In Brazil, A. conyzoides occurs in North, Northeast, Central West, Southeast, and South regions (Nakajima, 2010). Stem galls were found in this plant in the State of Minas Gerais (Southeast region). They are induced by a new species of Clinodiplosis Kieffer, 1894 (Diptera, Cecidomyiidae). In the present paper, these galls are characterized and the galler is described.

Clinodiplosis is a cosmopolitan genus with 104 described species, most being mycophagous, particularly the European ones, but there are also phytophagous species, especially in the New World. In the Neotropics, some species cause complex gall, and few are facultative predaceous (Gagné and Jaschhof, 2014).

The genus can be characterized by presenting occipital procces; four-segmented palpi; wings with 1-3 mm long, $\mathrm{R} 5$ joining $\mathrm{C}$ beyond the wing apex, Rs weaker than $\mathrm{R} 1$, but evident; variable tarsal claws (toothed or simple, and curved near basal third or beyond), empodia usually reaching to the curve of the claws or sometimes shorter; quadrate or secondarily lobed or acute male cerci; aedeagus usually elongate and tapering to the apex or sometimes large and bulbous; ovipositor short, barely protrusible; and female cerci separate.

Clinodiplosis comprises only 23 Neotropical species, 18 of them occurring in Brazil (15 with records only in Brazil and three with records also in other Neotropical countries). The genus is associated with 32 plant families, but only nine species have been recorded in Asteraceae (Gagné and Jaschhof, 2014): six in the Palaearctic Region: Clinodiplosis artemisiarum Kieffer, 1909; C. achyrophoridis Fedotova, 2004; C. cilicrus (Kieffer, 1889); Clinodiplosis cirsii Kieffer, 1909; C. oleracei Rübsaamen, 1917; and C. phalacrolamae Fedotova, 2004; and three in the 
Neotropics: C. bahiensis Tavares, 1917; C. cearensis Tavares, 1917; and C. eupatorii (Felt, 1911).

Nine genera of Asteraceae are known as host plants of Clinodiplosis spp.: Achyrophorus Adans., Artemisia L., Carlina L., Centaurea L., Cirsium Mill., Phalacroloma Cass., and Scabiosa L. in the Palaearctic Region, and Chromolaena DC. and Eupatorium L., in the Neotropics. Besides, two species from Brazil are associated with not determined Asteraceae (Gagné and Jaschhof, 2014). For the first time, Ageratum L. is recorded as host plant of Clinodiplosis species.

\section{Material and Methods}

Galled stems of Ageratum conyzoides were collected in municipality of Dores do Indaiá (State of Minas Gerais, Southeast Region, Brazil), in February of 2009. The collections were made in a shaded and newly cultivated area ( $45^{\circ} 68^{\prime} 57^{\prime \prime}$ long, $19^{\circ} 50^{\prime} 72^{\prime \prime}$ lat, $680 \mathrm{~m}$ of altitude) by L.A.

Samples of the host plant were collected, pressed and dried for preservation, being later identified by Andreia Fonseca Silva and incorporated into PAMG/EPAMIG Herbarium (record number: PAMG/EPAMIG: 56328).

Galled stems were removed from the host plant and transported in plastic bags to the laboratory, where part of the sample was dissected to obtain the galling larvae and part was kept in plastic pots covered by a fine screening to obtain adults and pupal exuviae. The specimens were first preserved in $70 \%$ ethanol and then mounted on microscope slides, following the methods of Gagné (1994).

The field and laboratory works were done by L.A. and the description of the new species by V.C.M.

Clinodiplosis agerati Maia, sp. n. (Figures 1-11)

Diagnosis. Flagellomere 12 with apical process, setulose in both sexes; tarsal claws simple and curved at basal third; male cerci secondarily deeply lobed; gonostyli 7.6 times as long as wide; aedeagus elongate, tapering to the apex and constricted subapically.

Larva. Fusiform and cylindrical body; 1.90-2.60 mm long $(\mathrm{n}=4)$. Integument rough. Spatula (Figure 1): 0.16-0.20 mm long $(n=4)$, two-toothed, apical teeth triangular with rounded apex, stalk six times as long as teeth. Two groups of three lateral papillae on each side of spatula (two pairs setose in each group) (Figure 1). Terminal segment (Figure 2): three pairs of corniform papillae, and one pair of setose papillae (setal length: $0.05 \mathrm{~mm} ; \mathrm{n}=4$ ).

Pupa. Body length: 1.8-2.1 mm ( $\mathrm{n}=2)$. Head (Figure 3): apical setae 0.08-0.09 mm long $(\mathrm{n}=2)$; two pairs of lower facial papillae (one asetose and the other setose), three pairs of lateral facial papillae, one pair setose and two without seta. Prothoracic spiracle (Figure 4) elongate $0.20-0.30 \mathrm{~mm}$ long $(\mathrm{n}=3)$ and thin. Foreleg sheath reaching the basal margin of abdominal segment 7 , midleg sheath reaching the midlength of abdominal segment 7 and hindleg sheath reaching the distal margin of abdominal segment 7. Abdominal segments 2-8 with conspicuous spines at basal $1 / 3$, restricted to mesal region; distal spines gradually crescent (Figure 5).

Adult. Body length: 1.50-1.80 mm ( $\mathrm{n}=06)$. Head (Figure 6): occipital process present. Eye facets hexagonal, all closely approximated. Antenna: flagellomeres 1 and 2 connate, male flagellomeres binodal and tricircumfilar, nodes setulose and necks bare; circumfila loops regular in length (Figure 7); flagellomere 5: 0.18-0.19 mm long $(n=4)$ : basal node five times shorter than the total length of the flagellomere, basal neck 5.5 times shorter than the total length of the flagellomere, distal node 3.5 times shorter than the total length of the flagellomere, and distal neck 2.8 times shorter than the total length of the flagellomere $(n=4)$; female flagellomeres cylindrical slightly constricted near midlength, node setulose and neck bare; flagellomere 5: $0.12 \mathrm{~mm}$ long $(\mathrm{n}=2)$, node 1.65 times shorter than the total length of the flagellomere $(n=2)$, circumfila as two connected horizontal rings (Figure 8). Flagellomere 12 with apical process, setulose in both sexes. Frontoclypeus with 10 setae. Labrum triangular, long-attenuate, with 3 pairs of ventral sensory setae. Hypopharynx shorter than labrum, with anteriorly directed lateral setulae. Labella 0.07-0.11 mm long $(n=4)$, elongate-convex, each with long lateral setae and two pairs of short mesal sensory setae. Palpus 0.13-0.17 mm long $(n=2)$, with four crescent cylindrical segments, all with setae.

Thorax. Wings: length: $1.7-2.1 \mathrm{~mm}(\mathrm{n}=6)$ in male $(\mathrm{n}=5)$, 1.9-2.4 mm in female $(n=4)$; venation: R1 2.8 times shorter than wing length, Rs present and evanescent, R5 curved, joining $\mathrm{C}$ beyond wing apex, $\mathrm{M} 3$ evanescent; $\mathrm{CuA}$ forked. Anepisternum bare. Anepimeron with 6 setae $(n=2)$. Tarsal claws simple, bent before midlength, gradually attenuate to apex; empodium short, reaching bent in claws (Figure 9). Male abdomen: tergites 1-7 rectangular with a distal row of setae and a basal pair of trichoid sensilla, tergite 8 not sclerotized with only a pair of trichoid sensilla. Sternites 2-7 rectangular with a caudal row of setae, irregular mesal rows of setae and a pair of trichoid sensilla; sternite 8 sclerotized, rectangular, conspicuously shorter than sternite 7 , with scattered setae near distal margin and at mesal region and a pair of trichoid sensilla. Female abdome: tergites 1-7 rectangular with a caudal row of setae, some lateral setae near mesal region and a pair of trichoid sensilla; tergite 8 shorter than the precedent, elongate, with a pair of trichoid sensilla and no setae. Sternites 2-8 rectangular with a caudal row of setae, scattered setae at mesal region, lateral setae present and a basal pair of trichoid sensilla. Male terminalia (Figure 10): gonocoxite with mesal lobe; gonostylus and gonocoxite subequal in length, gonostylus elongate, $0.15-0.16 \mathrm{~mm}$ long and $0.02 \mathrm{~mm}$ wide $(\mathrm{n}=3)$, striate except near basis, setulose basally; cercus setose and secondarily lobed; hypoproct narrow, conspicuously longer than cercus, deeply bilobed, and setose; aedeagus and hypoproct subequal in length, aedeagus $0.14-0.15 \mathrm{~mm}$ long $(n=3)$, triangular, constricted near apex and rounded apically. Ovipositor barely protrusible, female cerci (Figure 11) elongate-ovoid and setose, with a pair of 

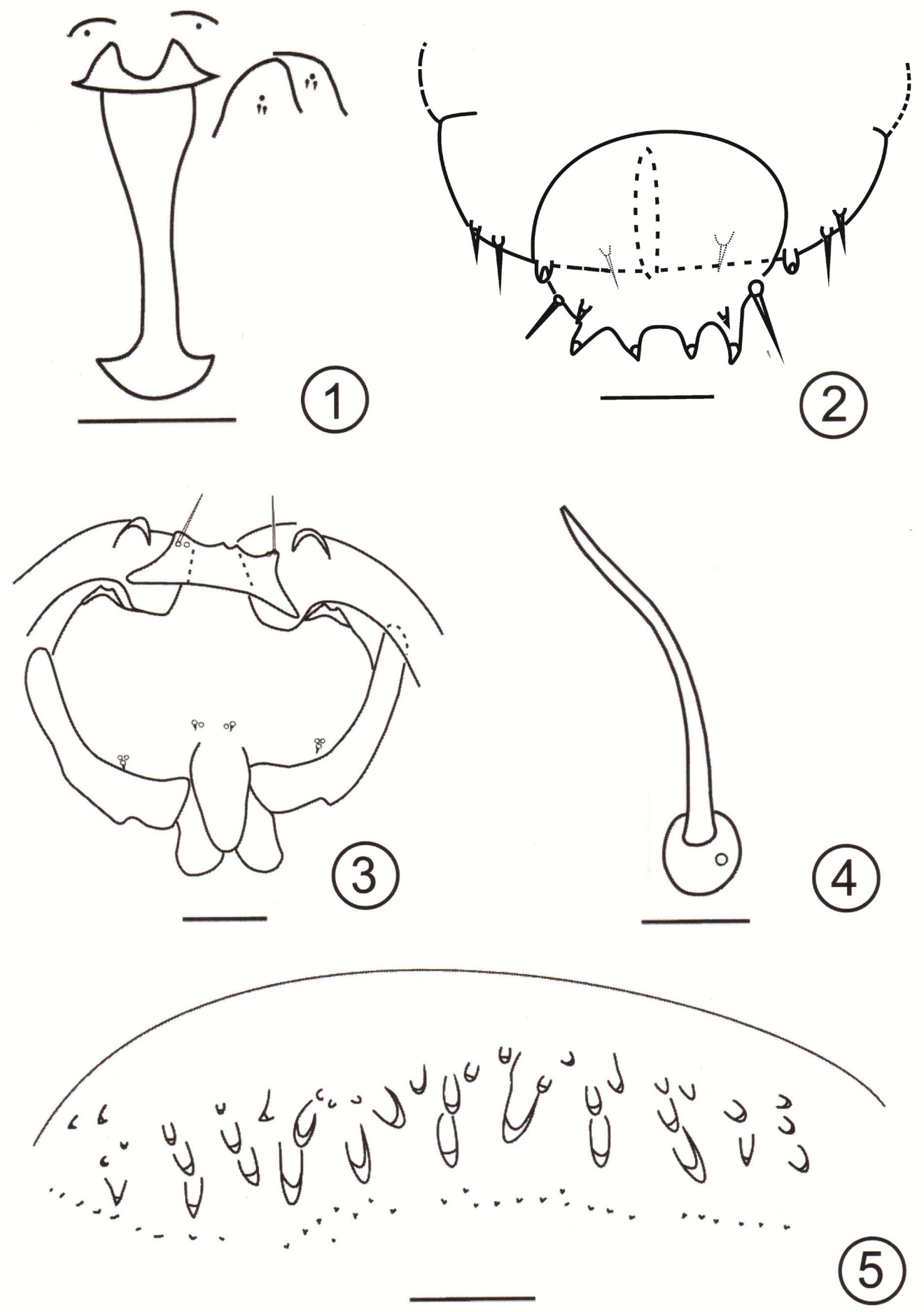

Figures 1-5. Clinodiplosis agerati, sp. n.: (1) larva, prothoracic spatula, sterna and ventral papillae, ventral view, scale bar: $0.05 \mathrm{~mm}$; (2) larva, terminal segment, dorsal view, scale bar: $0.10 \mathrm{~mm}$; (3) pupa, cephalic region, frontal view, scale bar: $0.10 \mathrm{~mm}$; (4) pupa, prothoracic spiracle, scale bar: $0.10 \mathrm{~mm}$; (5) pupa, abdominal segment 4, dorsal view, scale bar: $0.05 \mathrm{~mm}$. 

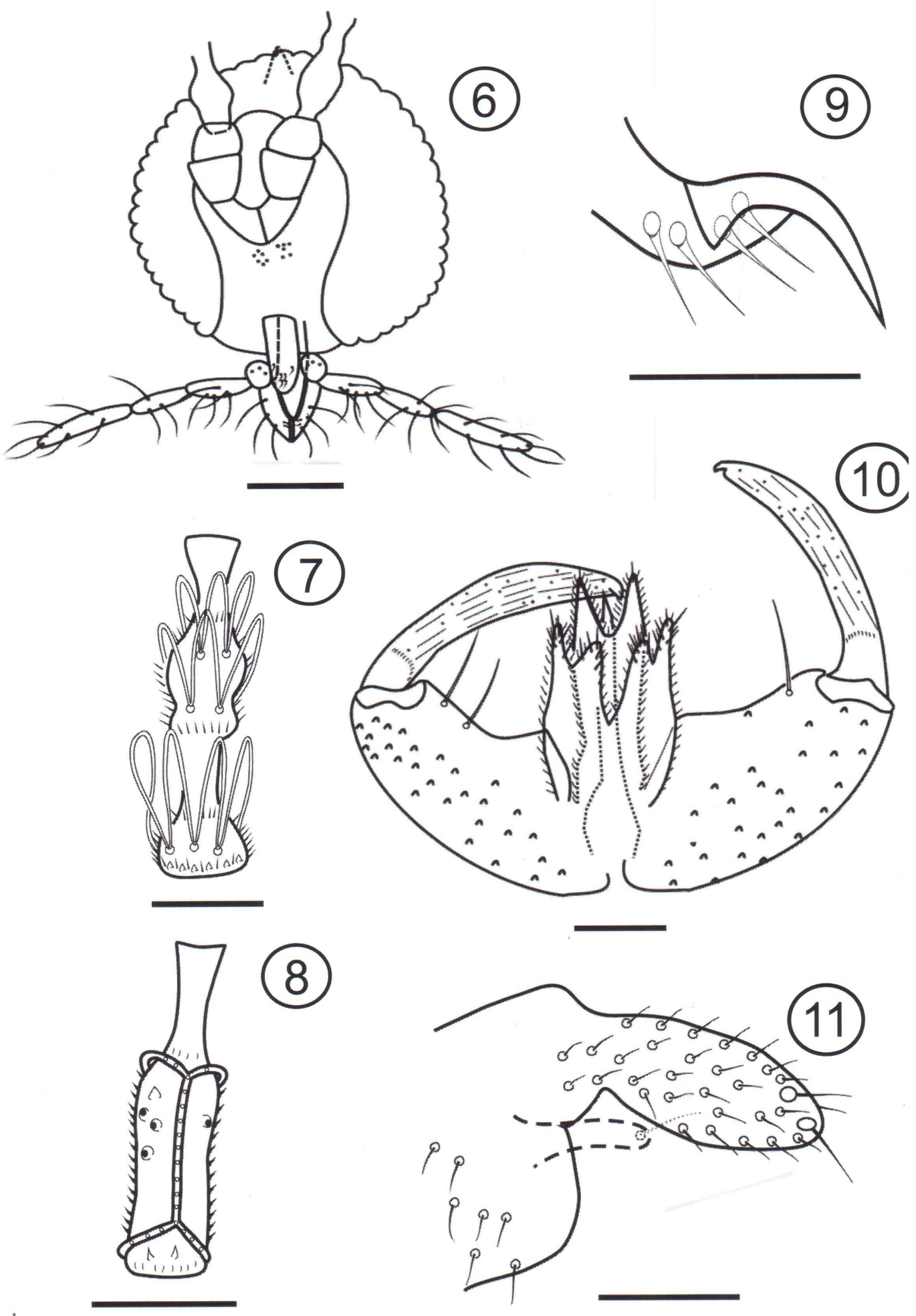

Figures 6-11. Clinodiplosis agerati, sp. n.: (6) male head, frontal view, scale bar: $0.10 \mathrm{~mm}$; (7) male flagellomere 5, scale bar: $0.05 \mathrm{~mm}$; (8) female flagellomere 5, scale bar: $0.05 \mathrm{~mm}$; (9) male foreleg, tarsal claw and empodium, scale bar: $0.03 \mathrm{~mm}$; (10) male terminalia, dorsal view, scale bar: $0.05 \mathrm{~mm}$; (11) female cerci and hypoproct, ventral view, scale bar: $0.05 \mathrm{~mm}$. 
apical seta stronger than others, female hypoproct narrow, elongate and setose.

Gall. Apical stem galls, spherical, green, with white trichomes, one-chambered (more than one galling larva per chamber) on Ageratum conyzoides (Asteraceae) (Figure 12).

Etymology. The name agerati refers to the genus of the host plant.

Material examined. Holotype male. Brazil, Minas Gerais, Dores de Indaiá, II.2009, Oliveira, L. A. leg., MNRJ. Paratypes, same locality, data and collector 4 males, 03 females, 3 pupal exuviae and 4 larvae, MNRJ. Additional material examined: same locality, data and collector -5 males and 3 females, MNRJ.

Comments. The Neotropical species of Clinodiplosis include adults with simple or toothed tarsal claws. The new species has simple ones, as the following species: C. alternantherae Gagné, 2004; C. bahiensis (Tavares, 1916); C. bellum Urso-Guimarães \& Carmo-Neto, 2015; C. cattleyae Molliard, 1903; C. cearensis (Tavares, 1916); C. conica Oliveira \& Maia, 2008; C. diodiae Maia, 2001; C. eupatorii (Felt, 1911); C. floricola Novo-Guedes \& Maia, 2008; C. iheringia (Tavares, 1925); C. marcetia (Tavares, 1917); C. melissae Maia, 1993; C. profusa Maia, 2001; C. pulchra (Tavares, 1917); and C. rubiae (Tavares, 1917). The majority of them have tarsal claws curved at the basal third (as the new species), excepting C. alternantherae, C. bellum, C. cattleyae, C. conica, and

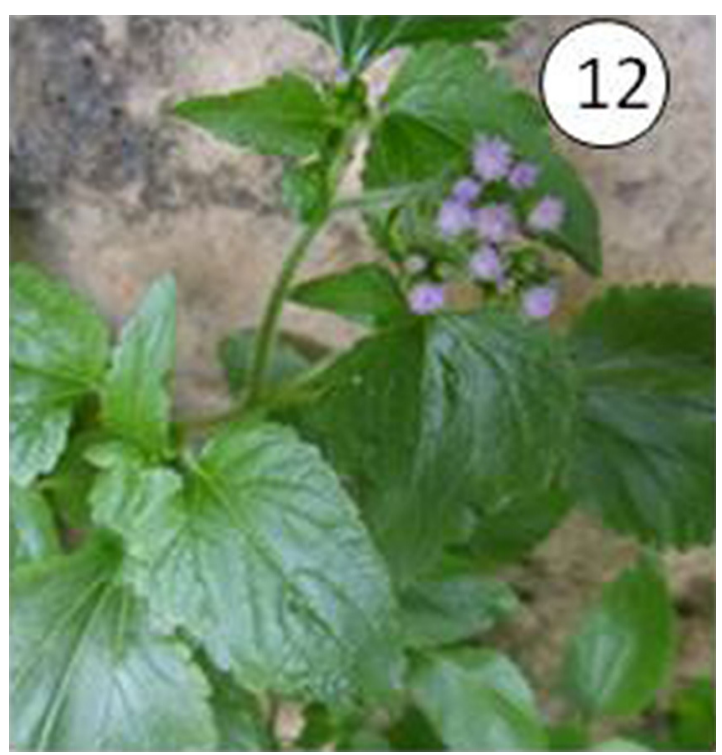

Figure 12. Ageratum conyzoides (Asteraceae): general aspect.
C. eupatorii. Among the species with tarsal claws simple and curved at the basal third, only three have male cerci secondarily deeply lobed (as the new species): $C$. diodiae, C. floricola, and C. profusa. The new species can be distinguishable from these three species by the spatula length $(0.12-0.15 \mathrm{~mm}$ in $C$. diodiae, $0.09-0.12 \mathrm{~mm}$ in C. floricola, 0.24-0.26 in C. profusa, and 0.16-0.20 mm in the new species), apical seta length $(0.16-0.18 \mathrm{~mm}$ in C. diodiae, $0.07 \mathrm{~mm}$ in C. floricola, $0.05 \mathrm{~mm}$ in C. profusa and $0.08-0.09 \mathrm{~mm}$ in the new species), proportion between gonostylus length and width (gonostylus 6 times as long as wide in C. diodiae and C. floricola, 9 times in C. profusa, and 7.6 times in the new species).

\section{Acknowledgements}

The authors are grateful to the M.Sc. Andréia Fonseca Silva (Epamig - Herbário PAMG - Empresa de Pesquisa Agropecuária de Minas Gerais) for plant identification and to the Conselho Nacional de Pesquisa e Desenvolvimento Científico $(\mathrm{CNPq})$ for financial support.

\section{References}

ACHOLA, K.J., MUNENGE, R.W. and MWAURA, A.M., 1994. Pharmacological properties of root and aerial parts extracts of Ageratum conyzoides on isolated ileum and heart. Fitoterapia, vol. 65 , pp. 322-325.

GAGNÉ, R.J. and JASCHHOF, M., 2014. A catalog of the Cecidomyiidae (Diptera) of the World. 3rd ed. Washington: USDA. Digital version 2.

GAGNÉ, R.J., 1994. The gall midges of the Neotropical region. Ithaca: Cornell University Press. 352 p.

MARQUES-NETO, J.F., LAPA, A. and KUBOTA, M., 1988. Efeitos do Ageratum conyzoides Lineé no tratamento da artrose. Revista Brasileira de Reumatologia, vol. 28, no. 4, pp. 34-37.

MOMESSO, L.S., MOURA, R.M.X. and CONSTANTINO, D.H.J., 2009. Atividade antitumoral do Ageratum conyzoides L. (Asteraceae). Revista Brasileira de Farmacognosia, vol. 19, no. 3, pp. 660-663. http://dx.doi.org/10.1590/S0102-695X2009000500002.

NAKAJIMA, J., 2010 [viewed 13 April 2015]. Ageratum. In: JARDIM BOTÂNICO DO RIO DE JANEIRO - JBRJ. Lista de espécies da flora do Brasil [online]. Rio de Janeiro: JBRJ. Available from: http://floradobrasil.jbrj.gov.br/2010/FB015934

SIQUEIRA-JACCOUD, R.J., 1961. Contribuição para o estudo farmacognóstico do Ageratum conyzoides L. Revista Brasileira de Farmácia, vol. 42, pp. 177-197.

YOGANARNARASIMHAM, S.N., 2000. Medicinal plants of India: Tamil Nadu. Bangalore: Regional Research Institute. 27 p. vol. 2. 